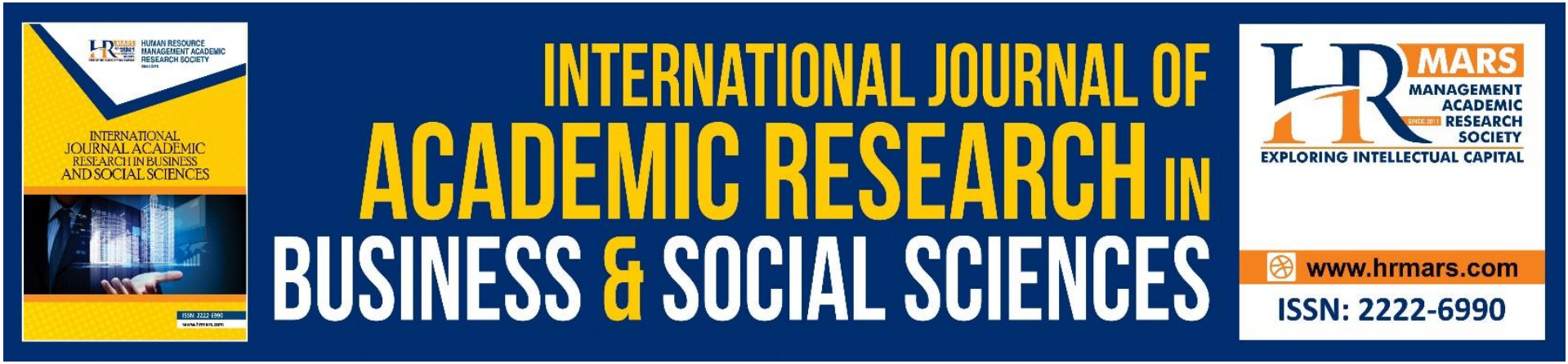

\title{
Psychological Contract, Employee Engagement and Employee Performance
}

\author{
Julius Samuel Opolot, Lydia Maket
}

To Link this Article: http://dx.doi.org/10.6007/IJARBSS/v10-i11/7998

DOI:10.6007/IJARBSS/v10-i11/7998

Received: 06 September 2020, Revised: 09 October 2020, Accepted: 02 November 2020

Published Online: 29 November 2020

In-Text Citation: (Opolot, \& Maket, 2020)

To Cite this Article: Opolot, J. S., \& Maket, L. (2020). Psychological Contract, Employee Engagement and Employee Performance. International Journal of Academic Research in Business and Social Sciences. 10(11), 886-903.

\section{Copyright: @ 2020 The Author(s)}

Published by Human Resource Management Academic Research Society (www.hrmars.com)

This article is published under the Creative Commons Attribution (CC BY 4.0) license. Anyone may reproduce, distribute, translate and create derivative works of this article (for both commercial and non-commercial purposes), subject to full attribution to the original publication and authors. The full terms of this license may be seen at: http://creativecommons.org/licences/by/4.0/legalcode

\section{Vol. 10, No. 11, 2020, Pg. 886 - 903}

Full Terms \& Conditions of access and use can be found at http://hrmars.com/index.php/pages/detail/publication-ethics 


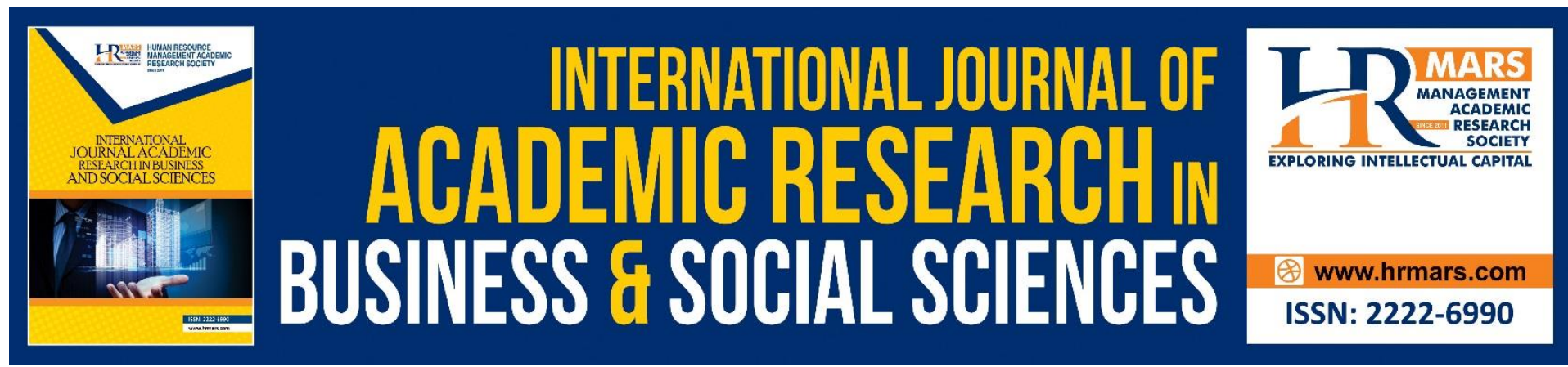

\title{
Psychological Contract, Employee Engagement and Employee Performance
}

\author{
Julius Samuel Opolot, Lydia Maket \\ Moi University, School of Business and Economics, Department of Management Science and \\ Entrepreneurship, Eldoret, Kenya
}

\begin{abstract}
Employees' performance is a critical element of the overall organizational performance in high performing companies, so its management is vital. Globalised economies have increased competition for organizations, so managers are under enormous pressure to improve performance and remain ahead of competitors. This paper looks at factors that improve the likelihood of organizations attaining peak performance. The paper examines the mediation effect of employee engagement on the relationship between employer obligations, employee obligations and state of the psychological contract and; employee performance. Due to different conceptualization of the psychological contract concept, this paper examines the concept from employer obligations, employee obligations and state of the psychological contract. The paper concludes that employee engagement assumes a critical precursor role to employee performance at the workplace.
\end{abstract}

Keywords: Psychological Contract, Employee Engagement and Employee Performance.

\section{Introduction}

Organizations have realized that they need to develop unique dynamic human resource (HR) capabilities that empower their sustainable competitive advantage in the ever constantly changing business environment (Diamantidis \& Chatzoglou, 2018). As such, they are focusing on the effective utilization of their human resources (Cascio, 1992), particularly on employee performance (Diamantidis \& Chatzoglou, 2018), as a source of strategic advantage (Wright and Snell, 2009)in the face of fierce competition (Boxall \& Macky, 2009).This explains why employee performance has remained a central issue in present day organizations as well as an area of concern for practitioners and researchers in the field of organizational behavior and human resource management (Mone, Eisinger, Guggenheim, Price, \& Stine, 2011). Employee performance is an indicator which measures how well an employee accomplishes the set targets in line with organizational objectives (Koech \& Cheboi, 2018). As a result, corporate entities both public and private worldwide are under tremendous pressure to ameliorate their performance (Singh, 2013).

Employee performance signifies individual's work achievement after exerting required effort on the job which is associated through getting a meaningful work, engaged profile, and compassionate colleagues/employers around (Hellriegel, Jackson, \& Slocum, 1999; Karakas, 2010). Improving employee performance and overall organization performance is the 
focus of every manager in an organization. In order to exploit HR fully and augment organizational success, business organizations need to design an effective employee performance management system (Pradhan \& Jena, 2016). This system will act an organizational to established comprehensive measurement index that provides managers and staff with clear directions through the set goals (Mone \& London, 2010; Ho, 2008; Tseng \& Lee, 2014). This awareness is supported by research findings from Rheem (1990) and Glenndinning (2002) as cited in Compton (2005) that there are "ample evidence to suggest that companies which utilize performance management systems can strategically perform more effectively...." The institutional performance driven objectives are expected to be aligned with the organizational policies so that the entire process moves away from being event driven to become more strategic and a people centric perspective (Jena \& Pradhan, 2014; London, 2003; Mone, \& London, 2010). For organizations, knowledge about employee performance and the factors that influence it represent a competitive advantage (Maia \& Bastos, 2019).

As organizational systems become more global, their complexity and performance challenges become more daunting (Broad, 2006), resulting in organizations needing to continuously review their practices to maintain and improve their competitive positions. The psychological contract (PC) has become a very important tool used to reduce the gap between employee expectations and employer obligations (Irving and Bobocel, 2002; Rousseau, 1995; Theron and Dodd, 2011).Straia (2011) describes PC as one of the modern methods used to motivate employees to enhance their performance and Wellin (2008) notes that PC can be used as a powerful vehicle to drive behavior and, more importantly, business performance. The Psychological Contract consists of the employees' individual beliefs regarding the terms and conditions of the exchange agreement between themselves and their organizations (Dabos \& Rosseau, 2004). Psychological Contract plays an important role to understand the contemporary employment relationship between employers and employees (Zhao et al., 2007; Augustina, 2014). Many scholars believe that perceptions of fulfillment of their unwritten expectations and obligations are important (Bal, Chiaburu\& Jansen, 2010; Kasekende, 2017).It is important that organizations understand employees' expectations in order to create value propositions that are mutually understood by both the organisation and the employees (De Vos et al., 2005). Employees and employers are assumed to have obligations towards each other and these obligations are interdependent (Coyle-Shapiro and Kessler, 2002). These obligations influence employee's subjective interpretations and evaluations of his/her relationship with the organisation. Generally, when employees are satisfied, committed and motivated in all cases, they will keep their promises to the organisation in the form of efficiency in performance.

Employee engagement is one of the key determinants fostering high levels of employee performance (Anitha, 2014). The concept of engagement has gained interest from both organizational practitioners and scholars (Quinones, Van den Broeck \& De Witte, 2013), who have globally been vocal on the need for organizations to devise strategies of ensuring employees are engaged at the workplace for organizational performance excellence (Gichochi, 2014). Employee engagement either makes or breaks organizations (Rao, 2017) and therefore engaged employees are described as an organization's greatest resource (Wagner \& Harter, 2011). Engaged employees display a positive emotional connection with their work by being optimistic, energetic, focus highly on work, and willing to work for the development of the organization (Jose \&Mampilly, 2012). Engaged employees help organizations to perform better (Naidoo, Abarantyne and Rugimbana, 2019). Employee 
engagement in this regard refers to "an individual employee's cognitive, emotional, and behavioral state directed toward desired organizational outcomes" (Shuck and Wollard, 2010). An engaged employee is aware of business context and works with colleagues to improve performance within the job for the benefit of the organization (Ologbo\&Sofian, 2013). Research has suggested that engaged employees are more likely to be productive, remain with their current employer and interact positively with customers (Chalofsky, 2010; Wright \& McMahan, 2011). Research evidence further indicates that employees' work engagement could became a sin qua non for the survival and growth of modern business organizations in the near future (Gallup, 2017; Luthans and Avolio , 2009; Schaufeli, 2013 ; Vadera, Pratt and Mishra, 2013). In fact majority of corporate executives are increasingly treating an engaged workforce as an organizational priority (Shuck and Wollard, 2010) since engaged employees are full of enthusiasm, show initiative at work, take responsibility for their own development, be energetic and dedicated to what they and do strive for high quality and performance (Bakker and Leiter, 2010). The above evidence shows that organizations with superior performance actively engage their employees.

However empirical results on employee engagement and employee performance show contradicting results both at employee level and organization level. The link between employee engagement and employee performance was sharply contrasted by Murphy (2013) in his study which linked employee engagement scores and employee appraisal scores. Murphy found that workers who were deemed to be low performers in their annual review scored higher than those employees who were viewed as high performers. He further established that highly engaged employees were low performers and that those employees who were low in engagement were high performers. Jaupi and Llaci, (2014) in their study 'Employee Engagement and its Relation with Key Economic Indicators' established that in Albania, the region that reported the lowest income per capita (GDP $24 \%)$, had the most employees engaged (76.4\%). These findings indicate a sharp contrast to years of research linking high employee engagement to increased employee performance, productivity, profitability and overall organizational performance. This implies that more research is needed to explore contrasting findings by researchers .Naicker(2013) Nazem, Mozaiini and Seifi(2014) agree that most empirical studies on employee engagement and have been done in developed economies and thus need for more studies in developing economies with varying institutions, demographics and cultural context.

\section{Employee Performance}

The concept of performance has gained increasing attention in recent decades, being pervasive in almost all spheres of the human activity (Iuliana and Maria, 2016). Employee Performance in the organizational setting is an accumulated result of the skills, efforts and abilities of all employees which leads to improved productivity and achievement of organizational goals (Mensah, 2015).Therefore improved organizational performance indicates the efforts towards goal achievement while requiring more efforts in terms of improved employee performance (Ellinger, Ellinger, \& Keller, 2003).

The concept of performance is of high relevance for individuals and organizations alike. As a result of its importance, it has received considerable research and practical attention. In spite of its significance and different researches in the field over the years, there is still no consensus and universally accepted definition of what performance is. For example, Sonnentag and Frese (2002) observe that despite the great relevance of individual performance and the widespread use of job performance as an outcome measure in empirical 
research, relatively little effort has been spent on clarifying the performance concept. Similarly, Campbell (1990) described the literature on the structure and content of performance as "a virtual desert" while Lebas and Euske (2002) stated that "performance is one of those 'suitcase words' in which everyone places the concepts that suit them, letting the context take care of the definition".

In spite of the controversies about the definition of performance, some attempts have been made by researchers, authors and practitioners to define the concept. For instance, Viswesvaran and Ones (2000) indicate that job performance refers to how resourcefully individuals take actions and contribute with behaviours that are in line with an organization's objectives. Performance as defined by Campbell et al., (1990) refers to "observable things people do that are relevant for the goals of the organisation". Campbell (1990), on the other hand, defines performance as what the organisation hires one to do and do well. Generally, performance has been assumed to be associated with an individual's ability to realize his/her work goals, fulfill expectations as well as attaining job targets and/or accomplish standards that are set by their organisation (Maathis and Jackson, 2000; Bohlander et al., 2001). According to Mensah (2015) notes that performance is a positive contribution of an employee to the performance of the organisation and such a detailed understanding of the concept requires a discussion of its dimensions.

\section{Dimensions of Employee Performance}

Employee performance has been considered as a multi-dimensional concept made up of task, contextual, adaptive and counterproductive behaviours (Motowidlo et al., 1997; Pulakos et al., 2000; Koopmans et al., 2011). Task performance includes patterns of behaviour that deliver direct support for the organisation's core technical processes (Van Scotter et al., 2000). Task performance covers actions that are part of the formal reward system, and addresses the requirements as specified in the job descriptions (Williams \& Karau, 1991). Contextual performance, on the other hand, refers to behaviours that are not directly related to the job, but support the psychological and social contexts in which task activities are performed (Borman \& Motowidlo, 1993; Koopmans et al., 2011). Adaptive performance is the ability to adapt to changes in work tasks, such as being flexible and versatile (Pulakos et al., 2000; Griffin et al., 2007). Counterproductive behaviour is a non-task behaviour that has negative consequences for both the organisation and the individual (Viswesvaran \& Ones, 2000; Rotundo \& Sackett, 2002).

\section{Psychological Contract}

Barnard's theory of equilibrium of 1938 referred to an employment relationship as an exchange, suggesting that an employee's continued participation in an organisation depended on adequate rewards received from the employer (Coyle-Shapiro \&Parzafall, 2008). The term 'psychological contract' was first used by Argyris in the early 1960s. This contract focuses explicitly on employees' perceptions of the employment deal (Höglund, 2012). At the basis of the psychological contract is social exchange theory, based on the principal of reciprocity. Reciprocity implies that an individual feels obliged to reciprocate when receiving a benefit (Sonnenberg, Koene, \& Paauwe, 2011). As such, these social contractual relationships benefits are often unspecified and can be either extrinsic or intrinsic (Kasekende, 2017).

Psychological contracts consist of individuals' beliefs regarding the terms and conditions of the exchange agreement between themselves and their organizations (Rousseau, 1989). 
Psychological contracts emerge when individuals believe that their organization has promised to provide them with certain rewards in return for the contributions they make to the organization (Turnley and Feldman 2000). The perception that promises are being fulfilled enhances commitment, intention to remain with the organization and organizational citizenship behaviours (Robinson and Morrison 1995; Conway and Briner 2002; Coyle-Shapiro 2002; Turnley et al. 2003; Sturges et al. 2005). Later these promises become the set of expectations and obligations that individual employees have as work experiences (Rousseau, 2012). These work experiences can be formed by the terms of supervisor \& subordinate differences Kasekende (2017). Many scholars agree that the psychological contract is the unwritten agreement that exists between the employee and employer that contains a set of mutual expectations.

Rousseau (2012) describes the psychological contract as the perceptions of reciprocal agreements that are held by two parties. Despite the importance of the psychological contract, there is an ongoing debate in the literature regarding the operationalisation of this construct(Kasekende, 2017). The proponents of psychological contract believed that the concept can be operationalised from a variety of perspectives (Augustina, 2014). For example, Rousseau (2012) operationalises the psychological contract to consist three elements: perceived employee obligations, perceived employer (organization) obligations, and perceived fulfillment/violation of employer obligations. This implies changes in the employment relationship that may have an impact on the viability thereof (Guest, 2004; Tyagi \& Agrawal, 2010), as well as on employees' subjective experiences of their work and the employment relationship (Rothmann \& Cilliers, 2007; Schreuder\& Coetzee, 2010).

However, Guest (1998) insists that there is another dimension of psychological contract, that is, the state of the psychological contract (SPC). Guest (1998) considers the state of the psychological contract an important precursor of employee behaviour and attitudes, beyond the variance explained by the content of the psychological contract. Coyle-Shapiro and Kessler (2002) indicated that this state of the psychological contract includes the reciprocal experience, where both employer and employee expectations are included. Thus, both employee expectations and obligations - from the employee's perspective - are included in the measurement of the state of the employee's psychological contract. Guest (1998) further argues that it is operationalised to include so many different psychological variables, with very little known about the relationships between them, that the psychological contract becomes an analytic nightmare. This study will examine the psychological contract from three dimensions, which are perceived employee obligations, perceived employer (organization) obligations, and the state of the psychological contract.

\section{Employer Obligations and Employee Obligations}

Beliefs about what the job will be like have been investigated in terms of expectations (Griffin, 2004). Expectations one party has of the other create an obligation on the other party to fulfill such expectations (Kasekende, 2017). As stated earlier, the concept of psychological contract seems to have no universally acceptable operationalisation as per existing extant literature. The most general Operationalisation of the psychological contract is the belief in obligations existing between two or more parties (Rousseau, 2012). Obligation is a commitment to future action, which the parties have agreed upon, even though the terms of the commitment, fulfillment and extent of mutuality opens a contract to contentions. Rousseau (2012) argues that individuals begin to formulate their side of the psychological contract (expected obligations) before they join the organization. Similarly, supervisors 
formulate their expectations of the employee just before they join the organization. Subsequent to the signing of an employment contract, the psychological contract (employee expectations vs employer obligations) evolves and shifts as both employer and employee modify their expectations of each other. Problems can and do arise when either party in the psychological contract feels cheated.

Other scholars who have studied the concept of psychological contract by examining the level of fulfillment of employee \& employer expectations and obligations of each other include Bal et al. (2010). According to Bal et al. (2010), the employee expects the employer (supervisor) to gain capability in general management areas, assist subordinates in monitoring and maintain systems. These hence become obligations on the part of the employer. The employer is further expected to look for ways to innovate and improve the organization and take risks and experiment, increasing the obligations they have towards the subordinate /employee (Bal, et al., 2010).

\section{The State of the Psychological Contract (SPC)}

The state of the psychological contract, as defined by Guest and Conway (2004), has broadened the construct of the psychological contract to include the core elements (trust and fairness) of the traditional employment relationship and to focus less on the promises made (content) and more on delivery. The state of the psychological contract is concerned with 'whether promises and obligations have been met, whether they are fair and their implications for trust' (Guest, 2004).

The state of the psychological contract (SPC) describes employees' subjective perceptions (accurate or not) of the actual human resource management (HRM) practices of their employer in comparison with their psychological contract (Guest, 1998). This state is directly related to, and yet distinct from the employees "psychological contract". According to both Guest (1998) and Rousseau (2012) the psychological contract refers to individuals' beliefs regarding the terms and conditions of an exchange relationship between themselves and their employer. Each employee holds beliefs regarding the "ideal" returns (Rousseau, 2012) their employer has agreed (either implicitly or explicitly) to provide him/her as exchange for his/her contribution. The state of the psychological contract (Guest, 1998) is thus operationalized as the employee's perceived discrepancy between this "ideal" return and the "actual" one they perceive as receiving from the organization such as compensation and rewards.

Guest (1998) identifies three key points in the state of the psychological contract: First the extent to which employers adopt people management practices will influence the state of the psychological contract. Secondly, the contract is based on employees' sense of fairness and trust and their belief that the employer is honoring the 'deal' between them. Lastly, where the psychological contract is positive, increased employee commitment and satisfaction will have a positive impact on business performance.

The discussion above seems to imply that conceptually, employer obligations and employee obligations and state of the psychological contract are distinct constructs (Bal et al., 2010; Guest, 1998; Rousseau, 2012). There also is empirical evidence that supports the discriminant validity of these three types of fit. For instance, research has reported low correlations between actual employer obligations and employee obligations and state of the psychological contract and perceived employer obligations and employee obligations and state of the psychological contract (Kasekende, 2014). Research using confirmatory factor analysis has also shown that employer obligations and employee obligations and state of 
the psychological contract are distinct (Kasekende, 2014). In aggregate, psychological contract has an effect on the engagement of workers (Quiñones, Van den Broeck\& De Witte, 2013).

\section{Employee Engagement}

Employee Engagement (EE) emerged in the organizational and business management literature about two decades ago (Simpson, 2009). Despite this, there is no consensus on what it means, as well as its characteristics (Albrecht, 2010; Saks and Gruman, 2014). In a nutshell, scholars are yet to reach a consensus as to the meaning of the concept.

The meaning of the term employee engagement, its drivers and measurement remains elusive among scholars and practitioners of the business contemporary society. In an attempt to develop common demonstrable concepts, theories, experiences and transformers both the academic community and commercial consulting firms have explored employee engagement at length without reaching an agreement. The concept has drawn attention and varied definitions depending on the perspective and major study area of focus (RuganziDiogene, 2017). Misconceptions about the concept that cropped up shortly after were observed and mainly attributed to the fragmented approach of defining it (Shuck and Wollard, 2010). Employee engagement is a good tool to help every organisation to strive to gain competitive advantage over the others. People is one factor that cannot be duplicated or imitated by the competitors and is considered the most valuable asset if managed and engaged properly. This point has been emphasised by Baumruk (2004), in that employee engagement is considered to be the most powerful factor to measure a company's vigor. Katz and Kahn (1966) have referred to the concept of engagement in their work related to organizational effectiveness. However, it was mentioned in general as one of a number of needs to be developed to provide an innovative and co-operative work environment leading to performance and effectiveness.

In 1990 Kahn (1990) introduced the concept of employee engagement, giving his now famous definition quoted by several authors namely, "the harnessing of organization members' selves to their work roles; in engagement, people employ and express themselves physically, cognitively, and emotionally during role performances"(Anitha, 2014).Further, Rich, Lepine and Crowford (2010) conceptualize engagement by measuring the degree to which employees invest their cognitive, physical, and emotional energies into their role. However, recent studies have distinguished the concept of job engagement from job commitment, involvement, and organizational citizenship behavior (Lee et al., 2014; Slatten and Mehmetoglu, 2011). According to these studies, what divides engagement from other constructs is the active use of cognitions and emotions with an emphasis on one's formal role performance (Saks, 2006). Thus, when an individual is engaged, the person is more likely to express himself cognitively, emotionally, and physically during the role performance (Kahn, 1990). According to Quinones et al. (2013), engaged employees have been found to be instrumental to organizational support since they actively perform their roles better consequently being productive. Chughtai and Buckley (2013) suggest that engagement is a vital source of competitive advantage, particularly in knowledge-intensive organizations. Engaged employees are most likely to drive innovation, growth and revenue, build new products and services, generate new ideas and ultimately help spur the economy. Because of their strong emotional connection to their organisation, they are willing to go the extra mile (Cesario \& Chambel, 2017). 
Work engagement has been also described with critical elements such as work focus, energy and absorption in a job. In the present study, we understand engagement to be a motivational construct, as defined by Schaufeli et al. (2002) as cited in Cesário and Chambel (2017)as a 'positive, fulfilling, work -related state of mind that is characterized by vigor, dedication, and absorption. Vigor refers to high levels of energy and mental resilience while working, the willingness to invest effort in one's work, and persistence even in the face of difficulties. Dedication is characterized by a sense of significance, enthusiasm, inspiration, pride and challenge at work. Absorption consists of being fully concentrated, happy and deeply engrossed in one' s work whereby time passes quickly, and one has difficulty detaching oneself from work'. Research indicates that engaged employees have high levels of energy are enthusiastic about their work and are often immersed in their job so that time flies by (Macey\& Schneider, 2008; May et al., 2004). Engaged employees received higher ratings on in-role and extra -role performance, indicating that engaged employees perform better and are willing to go the extra mile (Bakkeret al., 2004; Bakker \& Demerouti, 2008). The consequences of work engagement have been identified with job satisfaction, career satisfaction, wellbeing at work, high organizational commitment and intention to remain in the organization (Salanova, et al. 2003; Schaufeli \&Bakker, 2004).

\section{Theoretical Review}

The study will be guided by three theories namely; Social Exchange Theory, Goal Setting Theory and Self Determination Theory.

\section{Social Exchange Theory (SET)}

Homans (1958); Blau (1964); and Emerson (1976) were the ground breaking early researchers in SET and shared a widely accepted and still evolving framework that summarized relational behaviors (Chadwick -Jones, 1976). Blau (1964) defined social exchange as "favors that create diffuse future obligations, not precisely specified ones, and the nature of the return cannot be bargained about but must be left to the discretion of the one who makes it". At the core of social exchange theory is the norm of reciprocity of action between parties that are not set in any contractual framework to define the form, time, and degree of payback obligation. It is a voluntary reciprocal obligation behavior mediated by trust and gratitude that propels the individual making the gratuitous repayment (Gould-Williams \& Davies, 2005). Blau viewed social exchange as the reward activity related to others' reactions. Implied was a "two -sided, mutually contingent, and mutually rewarding process involving 'transactions' or simply 'exchange"' (Emerson, 1976). "Social exchange theory has been one of the most influential conceptual paradigms for understanding workplace behavior" (Cropanzano\& Mitchell, 2005) and was represented when "workers seek a mutually beneficial and just relationship with their organization" (Chin \& Hung, 2013). Social exchange involves the idea that reciprocal favors are done with an assumption that later returns will occur (Aryee, Budhwar, \& Chen, 2002). Specificity relative to the return may not be articulated, because social exchange rests on a more discretionary expectation. The motivation for the exchange is also paramount, and the actors must view the exchange as charitable rather than based on self -interest (Karagonlar et al., 2016).

Application of SET in the workplace rests on the assumption that SET represents appealing actions of the company directed at its employees. Emerson noted that the nomenclature of social exchange theory has evolved to include "reward, reinforcement, cost, value, utility, resource, comparison level, transaction, profit, outcome, etc. (and) is an unconsolidated 
blend of ordinary speech and the technical vocabularies of research disciplines, notably psychology and economics" (Emerson, 1976). Social exchange theory has advanced with the works of Bentein and Guerrero (2008), who positioned it as a structure which explains one's workplace from an individual perspective (Jepsen, 2010). It also serves to establish reciprocal obligations from the employee. Conversely, work attitudes can become negative in response to unfavorable treatment (Ko\&Hur, 2014).

\section{Goal Setting Theory - GST}

The theory of goal setting has been extensively researched in the past four decades. Mitchell and Daniels (2003) as cited in (Latham \& Pinder, 2005) argue that goal setting "is quite easily the single most dominant theory in the field with over a thousand articles and reviews published on the topic in a little over 30 years". The theory began with the early work on levels of aspiration developed by Kurt Lewin and has since been primarily developed by Dr. Edwin Locke, who began goal setting research in the 1960s. The research revealed an inductive relationship between goal setting and improved production performance. The term "goal", is a common concept that encompasses other concepts like "intention, task, deadline, purpose, aim, end and objective" and is deemed as a "regulator of action" (Locke \& Latham, 1990). A goal can also be viewed as the aim of an action or task that a person consciously desires to achieve or obtain (Locke \& Latham, 2002, 2006). Significantly, according to Hale and Whitlam (1998), "whether they are known as goals, targets or objectives, organizations are constantly seeking ways of achieving them because "target setting is seen as a means of helping all employees to pull in the same direction with a view to gaining competitive advantage." Locke and Latham (1990) reinforced the argument that "There is strong reason to conclude that goal setting works at the group and organizational (or unit) level as well as at the individual level."

Sauers and Bass (1990) define goal setting as "a formal program of setting numerical or quantitative performance goals for individuals" and that "all formal goal setting programs share the common objectives of increasing employee motivation and performance." Goal setting involves the conscious process of establishing levels of performance in order to obtain desirable outcomes. The major the source of motivation according to GST is the desire and intention to reach a goal (Martin \& Pear, 2015). The importance of goal is aptly defined by Mills (2002) as representing "a way of keeping score" and that "by helping employees define their personal goals, managers are putting them on the path towards achieving the organisation goals." If individuals or teams find that their current performance is not achieving desired goals, they typically become motivated to increase effort or change their strategy (Locke \& Latham, 2006).

The theory proposes that human beings are more motivated to act when there is a reward at the end of the performance of a task or behaviour. The goal theory proposes that a reward at the end of a task acts as a motivation for the performance of that said task (PSU, 2014). The reward, however, should be clearly stated. The end state can be the reward itself. It is proposed that to have an efficient goal, three components must exist: proximity, difficulty, specificity and feedback (Femi, 2013). An ideal goal is a goal where the time between the reaching out and the end state is close. Further, it should be moderate in difficulty, neither too easy to present some challenge, nor too difficult, so that success can be possible. The theory also underscores the specificity of the goal. The individual must understand what is expected out of him, to start out for the goal. A specific goal gives direction of focus to that specific goal and away from distractions. Feedback is necessary 
for measuring progress towards the goal and makes it possible to know whether the level of efforts is adequate and in proper direction or needs corrections (Wanjala \& Kimutai, 2015).

The relevance of this theory to the research study can be attributed to the works of (Locke \& Latham, 2002; Locke \& Latham, 2006) that highlights four mechanisms that connect goals to performance outcomes. First, goals direct attention to priorities; that is when specific goals are set for workers, it drives their attention to priorities of achieving the goals. Second, they stimulate effort, whereby goals set are attached to specific reward system that stimulates workers to work better and effectively. Third, they challenge people to bring their knowledge and skills to bear and increase their chances of success. Fourth, the more challenging the goal, the more people will draw on their full range of skills.

\section{Self-Determination Theory SDT}

Deci and Ryan (1985) propose two overarching forms of motivation. Intrinsic motivation refers to doing an activity for its own sake out of enjoyment and interest. Extrinsic motivation refers to doing an activity for instrumental reasons. Although extrinsic motivation is arguably predominant in a work context, it too can take different forms. According to SDT, extrinsic motivation can reflect a desire to gain rewards or avoid punishment (external regulation), boost one's ego or avoid feelings of guilt (introjections), attain a valued personal goal (identification), or express one's sense of self (integration). Identification and integration involve a high level of volition and, along with intrinsic motivation, are considered forms of autonomous regulation. External regulation and introjections involve more external influence and less authenticity and are considered forms of controlled regulation. Autonomous regulation, which is also at the heart of Sheldon's concept of self-concordance and Vallerand's characterization of harmonious passion, has been demonstrated to lead to higher levels of performance, persistence, initiative, and creativity (Ryan \& Deci, 2000).

The concept of autonomous regulation overlaps considerably with Macey and Schneider's conceptualization of state engagement. Moreover, the behavioral outcomes found to be associated with autonomous regulation correspond with what they described as behavioral engagement. In contrast to recent conceptualizations of engagement, however, SDT has been in place for over 30 years, has been well tested in both laboratory and field research, and has served as a guide for training and interventions in a variety of contexts. Although much of the research has taken place outside of the work-place, there has been sufficient application in a work context to attest to its relevance (Gagne \& Deci, 2005). Thus, SDT is a theory that we believe can bring together existing conceptualizations and serve as a guide for future research.

According to SDT, the key to autonomous regulation is satisfaction of basic psychological needs for competence, autonomy, and relatedness. There is good evidence for the universality of these needs, and research shows that lack of satisfaction leads to poorer performance and reduced physical and psychological well-being (Ryan \& Deci, 2000). Moreover, need satisfaction is an important mediator in the relation between environmental influences (e.g., job characteristics, leadership) and autonomous regulation (Gagne \& Deci, 2005). Therefore, by identifying key mechanisms, SDT can serve as a useful guide for the development of targeted intervention strategies.

Macey and Schneider note that there is some confusion about whether the opposite of engagement is lack of engagement or disengagement. SDT distinguishes autonomous regulation (engagement) from controlled motivation and a motivation (i.e., with-drawal). 
Each can be measured individually, and these measures have been shown to relate differently to task-relevant behavior (Gagne \& Deci, 2005). In addition, there is a third motivational state identified within SDT that can also be contrasted with engagement reactive autonomy. Koestner and Losier (1996) have shown that people sometimes react to loss of autonomy by rebelling against the source of control. Thus, SDT helps to explain not only engagement but also the psychological states and behavioral reactions that can result in the absence of engagement.

Macey and Schneider focus primarily on task performance and organizational effectiveness as outcomes of engagement. These are indeed important outcomes. However, SDT research has consistently demonstrated that individuals who are "engaged" in what they are doing also experience greater physical and psychological well-being than those who are amotivated or lack of personal control (Ryan \& Deci, 2000). The well-being of employees is important in its own right and also has benefits for organizations in terms of lower absence rates and health insurance costs.

There is currently a lack of consensus regarding the measurement of engagement. For many years, SDT has been used to guide the measurement of engagement relevant variables (e.g., need satisfaction, motivational states, psychological and behavioral outcomes) in a variety of contexts (Ryan \& Connell, 1989). Vallerand (1997) has shown that motivational states can be operationalized at varying levels of abstraction: global (dispositional), contextual (work, education), and situational (specific activities). Consequently, SDT can readily be applied in the development of measures of the various facets of engagement identified by Macey and Schneider (trait, state, behavior) as well as various foci of engagement (job, organization; Saks, 2006). It can also be applied across domains (work, education, sport) to promote consistency in conceptualization and measurement and facilitate cross-fertilization.

There is agreement with Macey and Schneider that engagement is distinguishable from general work motivation, commitment, job involvement, job satisfaction, and other key concepts in the organizational behavior literature. However, we believe that the similarities and differences might be more clearly articulated by grounding the concept of engagement in SDT. For example, one of the reasons that Macey and Schneider viewed engagement as distinct from work motivation is that most theories of work motivation focus primarily on intensity without much concern for form. SDT, in contrast, offers a multidimensional conceptualization of work motivation that allows one to differentiate forms of motivation (controlled vs. autonomous) and their implications for behavior (effective in-role performance vs. the discretionary and a typical performance believed to characterize behavioral engagement). Consequently, by grounding engagement in SDT, engagement can be embedded within motivation theory where it intuitively belongs. As an added benefit, engagement theory and research can be informed by recent work linking SDT with theories of commitment, leadership, identification, and job design (Meyer, Becker, \&Vandenberghe, 2004).

\section{Employee Engagement and Employee Performance}

Employee performance is basically the outcomes achieved and the accomplishments made (Anitha 2014), as well as behaviours put up at work (Aguinis, 2009). An important way to enhance employee performance is to focus on fostering employee engagement since engaged employees are willing to make all efforts to help the organisation achieve its goals. Employee engagement relates to task performance because engaged employees make use of high levels of their energies, concentrate on assigned work and are able to cope with adversity 
(Breevaart et al., 2014). Thus, when employees are engaged, they are ready to go the extra mile to ensure goals are accomplished at the work place and performance improved.

Since the inception of engagement construct, researchers have studied various aspects of employee engagement. It is evident from extant literature that employee engagement has an impact on organization results both at employee level and organization level. From employee level perspective, a study by Hakanen, Perhoniemi, Toppinen-Tanner found a positive relationship between employee engagement and employee initiative over time. Halbesleben and Wheeler (2008) conducted a study with a sample size of 587 employees and established a significant relationship between employee engagement and performance and the results were consistent when employee performance was rated by supervisors, co-workers and even self. Fredrickson (2001) in his study established that engaged employees are more receptive to new experiences thus they tend to explore their environments leading to more innovation and creativity at work.

This view is supported by Bakker, Demerouti, Ten Brummelhuis (2012) who posited that engaged employees are more willing to learn new things. This shows that engaged employees are able to translate their thoughts to action and therefore achieve high performance in the work place (Halbesleben\& Wheeler, 2008; Demerouti\&Cropanzano, 2010). Kim, Kolb, and Kim (2012) reviewed empirical studies on employee engagement and performance and established that existing empirical studies confirms direct and/or indirect positive effects of employee engagement on employee performance within organizations. Kruse (2012) did an analysis of 28 research studies by different scholars and revealed that there is a correlation between employee engagement and service, sales, quality, safety, retention, profits and total shareholder returns.

The link between employee engagement and employee outcome is further supported by Wagner and Saks, Harter and Fleming and Asplund who articulated that engaged employees often portray a deep positive emotional connection with their work and are consistently more productive, profitable, safer, healthier and less likely to leave their employer. This finding further agrees with Harter et al. (2002) who conducted a metaanalysis and found that employee engagement relates to higher profitability and customer satisfaction hence customer loyalty. This view is further supported by a four year longitudinal study by Winkler et al. Who used 755 retail bank employees to assess employee engagement on business unit metrics and established that employee engagement had more impact on business results. A significant amount of research shows that engaged employees tend to outperform their disengaged counterparts (Shuck \& Reio, 2011).

A study by Rampersad pointed out that disengaged employees can be a serious liability to the organization as it causes organizations to incur excess costs as a result of underperformance on crucial tasks, leading to widespread customer dissatisfaction. The study pointed out major causes of employee disengagement as lack of trust between employee and management, unhealthy competition, bullying, harassment, excess control, toxic politics and poor level of equity in pay packages. Therefore, a disengaged employee or team is ready for exit from the organization and thus, there is need for organizations to engage employees at all levels.

However according to Murphy, (2013) it is no longer the case anymore that highly engaged employees are high performers in all areas. The link between employee engagement and employee performance was sharply contrasted by Murphy (2013) in his study which linked employee engagement scores and employee appraisal scores. Murphy found that 
workers who were deemed to be low performers in their annual review scored higher than those employees who were viewed as high performers. He further established that highly engaged employees were low performers and that those employees who were low in engagement were high performers.

These findings indicate a sharp contrast to years of research linking high employee engagement to increased employee performance, productivity, profitability and overall organizational performance. This implies that more research is needed to explore the concept of employee engagement because of the contradicting findings. This confirms the theoretical perspectives of Rana, Ardichvili and Tkachenko (2013) who articulated that there is no consensus on the relationships between employee engagement and other organizational variables.

\section{Mediating Role of Employee Engagement}

As a motivational construct, employee engagement has been found to play a suitable mediator role associated with several outcomes, and such has been used in several studies. For researchers to test the effect of a mediating variable in the relationship between independent and dependent variables, three conditions should be met (Alias, Noor \& Hassan, 2014) there should be a direct relationship between the independent variable and the dependent variable, a direct relationship between the independent variable and the mediating variable and a direct relationship between the mediating variable and the dependent variable. In a study conducted in Indonesia in the hotel sector, Suharti and Suliyanto (2012) found that employee engagement mediates the effect of organizational culture and leadership style on employee loyalty.

Ram and Prabhakar (2011) studied the mediating role of employee engagement in the relationships between potential antecedents of engagement and work-related outcomes such as job satisfaction and involvement. The authors studied four antecedents: job characteristics, rewards, organizational and supervisory support and employees' perceptions of organizational justice. Using a sample of 310 subjects working for Jordanian hotels, their findings confirmed the effect of all these variables on employee engagement, which in turn predicts the stated organizational outcomes. Anderson (2014) verified the mediating effect of employee engagement in the relationship between hindrances and challenging demands, high involvement and workgroup outcomes (i.e. job satisfaction, productivity and safety).

In another study by Darko (2019) in Electricity Company of Ghana (ECG) a public sector organisation focusing on the relationship between leader behavior (Transactional and Transformational) and employee task performance, particularly the function of Employee engagement as a mediator between these relationships. Data was gathered from 411 permanent employees and analyzed using partial least square-structural equation modeling (PLS-SEM) technique. Results showed that employee engagement mediates partially the relationship between transformational leader behavior and employee task performance unlike the relationship between transactional leader behavior and employee task performance. The results confirm findings of a research by Evelyn and Hazel (2015) who used civil servants in Kenya and found that employee engagement mediated the relationship between transformational leadership and performance.

Similarly, it has also been suggested that employee engagement may provide the key to unlock the black box of HR systems and performance linkage (Alfes, Shantz, Truss \&Soane, 2013). In the context of first line full-time employees and their managers employed in Romanian hotels in the Poiana Brasov region, work engagement played a considerable role 
as a full mediator in the relationship between HPWS and job performance and extra-role customer service.

\section{Contributions to Literature}

This being a conceptual paper, this study makes several contributions to literature in this area. First, the concept of the psychological contract has been extended to include fairness and trust. We concentrated on the predictive ability of the state of the psychological contract, including fulfillment, in relation to individual outcomes. The majority of research has focused on the content of the psychological contract (Conway \& Briner, 2005, 2009; Gracia et al., 2007) and the antecedents and consequences of fulfillment or breach (Conway \&Briner, 2005, 2009). This study contributes to research by exploring different dimensions of the psychological contract (content, trust, and fairness) and its ability to predict individual outcomes. It also enhances understanding of the unique explanatory power of fulfillment.

Second, employee engagement has proved to be a valid mediator in the relationship between the state of the psychological contract and employee performance. The research contributes toward the investigation of mediating variables in psychological contract research, with less focus on content but more on processes. Third, this research assists with identifying predictors of employee performance and with identifying whether these predictors have a direct or indirect effect on outcomes. The study contributes to the bulk of research on employee performance by determining the impact of negative evaluation of the state of the psychological contract and employee engagement.

An additional contribution of this research was that both the employee expectations and employee obligation variables had to be included in the state of the psychological contract construct to have an acceptable model fit. This confirms Rousseau's (1995) definition of the psychological contract that includes both expectations and obligations in the psychological contract, as well as Coyle-Shapiro and Kessler's (2002) view that both should be included in the state of the psychological contract.

\section{Conclusion}

This study examines the effect of psychological contract and employee performance. In order for managers to retain and secure top performance from their talented employees they must have a deeper understanding of the basic construct of their psychological contracts. This is particularly important as the contemporary employment relationship has become very complex. As such, employee performance can be observed by ensuring fulfillment of employer obligations, employee obligations and state of psychological contract for employee engagement. When the psychological contract is honored, it helps in shapes the behaviour of the parties and also aids the management to effectively manage their employees. Being so, psychological contract turns out to be advantageous for both the employers and the employees. For a psychological contract to be fulfilled, and ascertaining vibrant and effective employees, the communication of expectations between either of the parties plays an important role, thereby impacting on levels of employee engagement.

Tracing the sustainability and consistency of preserving a contractual state and obligations implies on acting in good faith, respecting and sharing equal concern for each other's interests. This acts as an obvious requirement in any relationship. Saying thus, both the employer and employee will have to create good intentions, confidence and feelings of attachment in the minds of each other which will in return strengthen their bond 
and also influence on how they intend to behave and reciprocate their mutuality towards each other. So once employees perceive management to be always responsive to their obligations, this will drive increased levels of engagement leading to subsequent improved employee performance.

\section{References}

Aguinis, H. (2009). Performance Management (2nd ed.). Upper Saddle River: Pearson Prentice Hall.

Agyemang, C. B., \& Ofei, S. B. (2013). Employee work engagement and organizational commitment: A comparative study of private and public sector organizations in Ghana. European Journal of Business and Innovation Research, 1(4), 20 -33.

Albrecht, S. L. (2010). Employee engagement: 10 key questions for research and practice. In $\mathrm{S}$.

Alfes, K., Shantz, A. D., Truss, C., \& Soane, E. C. (2013). The link between perceived human resource management practices, engagement and employee behaviour: A moderated mediation model. The International Journal of Human Resource Management 24(2):330-351, DOI: 10.1080/09585192.2012.679950

Alias, N. E., Noor, N. M., \& Hassan, R. (2014). Examining the Mediating Effect of Employee Engagement on the Relationship between Talent Management Practices and Employee Retention in the Information and Technology Organizations in Malaysia. Journal of Human Resources Management and Labor Studies, 2(2), 227-242.

Al-Tit, A. A., \& Hunitie, M. (2015). The Mediating Effect of Employee Engagement between Its Antecedents and Consequences. Journal of Management Research 7(5) 51.

Anitha, J. (2014). "Determinants of employee engagement and their impact on employee performance", International Journal of Productivity and Performance Management,63(3): 308 - 323. http://dx.doi.org/10.1108/IJPPM-01-2013-0008

Bakker, A. B., Demerouti, E., \& Ten Brummelhuis, L. L. (2012) Work engagement, performance, and active learning: The role of conscientiousness. Journal of Vocational Behavior. 80:555-64.

Breevaart, K., Bakker, A., Hetland, J., Demerouti, E., Olsen, O. K., \& Espevik, R. (2014).Daily transactional and transformational leadership and daily employee engagement. Journal of Occupational and Organizational Psychology, 87(1), 138-157.

Borman, W. C., \& Motowidlo, S. M. (1993). Expanding the Criterion Domain to Include Elements of Contextual Performance. Personnel Selection in Organizations. Jossey-Bass, San Francisco, 71- 98.

Conway, N., \& Briner, R. B. (2009). Fifty Years of Psychological Contract Research: What do we Know and What are the Main challenges? International Review of Industrial and Organizational Psychology, 24, 71-130.

Conway, N., \& Briner, R. B. (2005). Understanding Psychological Contracts at Work. A Critical Evaluation of Theory and Research, Oxford University Press, Oxford

Coyle-Shapiro, J., \& Kessler, I. (2002). A Psychological Contract Perspective on Organizational Citizenship Behavior. Journal of Organizational Behavior, 23, 927-946.

Demerouti, E., \& Cropanzano, R. (2010). From thought to action: employee work engagement and job performance. In: Bakker, A.B. \& Leiter, M.P (Eds) Work Engagement: A Handbook of Essential Theory and Research. New York. Psychology Press, pp. 147-163. 
Fredrickson, B. (2001) The role of positive emotions in positive psychology: the broadenand-build theory of positive emotions. Am. Psychol. 56:218-26.

Gracia, F. J., Silla, I., Peiro, J. M., \& Fortes-Ferreria, L. (2007). The state of the psychological contract and its relation to employees' psychological health. Psychology in Spain, 2(1), 33-41.

Halbesleben, J. R. B., \& Wheeler, A. R. (2008). The relative role of engagement and embeddedness in predicting job performance and intention to leave. An International Journal of Work, Health \& Organisations. 22(3), 242-56. https://doi.org/10.1080/02678370802383962

Harter, J. K., Schmidt, F. L., \& Hayes, T. L. (2002). Business-unit-level relationship between employee satisfaction, employee engagement, and business outcomes: A metaanalysis. Journal of Applied Psychology. 87(2):268-79

Ho, L. A. (2008). What affects organizational performance? The linking of learning and knowledge management. Industrial Management \& Data Systems, 108(9), 1234-1254.

Jaupi, F., \& Llaci, S. (2014). Employee engagement and its relation with key economic indicators. Journal of IT and Economic Development, 5(2): 112-122.

Karatepe, O. M. (2013). High-performance work practices and hotel employee performance: The mediation of work engagement. International Journal of Hospitality Management 32: 132-140. Doi: 10.1 016/j. ijh m. 2012.05.003

Kahn, W. (1990). Psychological conditions of personal engagement and disengagement at work. Academy of Management Journal, 33, pp. 692-724.

Kim, W., Kolb, J. A., \& Kim, T. (2013). The relationship between work engagement and Performance: A review of empirical literature and a proposed research agenda. Human Resource Development Review. 12(3), 248-276. Doi: $10.1177 / 1534484312461635$

Kruse, K. (2012). Why Employee Engagement. Retrieved Febuary 5, 2015, from http://www.kevinkruse.com/employee-engagement-research-master-list-of-29studies

Koopmans, L., Bernaards, C. M., Hildebrandt, V. H., Schaufeli, W. B., De Vet Henrica, C., \& Van Der Beek, A. J. (2011). Conceptual frameworks of individual work performance: A systematic review. Journal of Occupational and Environmental Medicine, 53 (8), 856866.

Mone, E. M., and London, M. (2010). Employee Engagement: Through Effective Performance Management - A Practical Guide for Managers. Taylor \& Francis Group NY.

Murphy, M. (2013). New analysis linking engagement scores with appraisal scores. Retrieved March 3, 2015, from https://www.leadershipiq.com/white-papers/job-performancenot-a predictor-of-employee-engagement/

Nasiruzzaman, H. A., Qudaih, R., \& Ahmad, D. (2013). Project success and knowledge management (KM) practices in Malaysian institution of higher learning (IHL). Journal of Education and Vocational Research, 4(5): 159-164.

Nazem, F., Mozaiini, M., \& Seifi, A. (2014). A structural equation model of knowledge management based on organizational climate in universities world academy of science, engineering and technology. International Journal of Social Management, Economics and Business Engineering, 8(2): 462-466.

Obuobisa-Darko, T. (2019). Leaders' Behaviour as a Determinant of Employee Performance in Ghana: the Mediating Role of Employee Engagement. Public Organization Review https://doi.org/10.1007/s11115-019-00460-6 
Quinones, M., Van den Broeck, A., \& De Witte, H. (2013). Do job resources affect work engagement via psychological empowerment? A mediation analysis. Journal of Work and Organizational Psychology 29(3), 127-134.

Rana, S., Ardichvili, A., \& Tkachenko, O. (2013). Theoretical model of the antecedents and outcomes of employee engagement: Dubin's method. Refereed proceedings of the 14th International Conference on Human Resource Development Research and Practice across Europe. University Forum for Human Resource Development (UFHRD), Brighton, UK: Academy of Human Resource Development.

Rao, M. S. (2017). Innovative tools and techniques to ensure effective employee engagement. Industrial and Commercial Training, 49 (3), 127-131.

Rothmann, S., \& Cilliers, F. V. N. (2007). Present challenges and some critical issues for research in industrial/organisational psychology in South Africa. South African Journal of Industrial Psychology, 33(1), 8-17.

Schaufeli, W. B., Salanova, M., Gonzalez-Roma, V., \& Bakker, A. B. (2002). The measurement of engagement and burnout: a two sample confirmatory factor analytical approach. Journal of Happiness Studies 3 (1):71-92.

Schreuder, A. M. G., \& Coetzee, M. (2010). An overview of industrial and organisational psychology research in South Africa: A preliminary study. South African Journal of Industrial Psychology, 36(1), 11. Doi:10.4102/sajip.v36i1.903

Shuck, B., \& Reio, T. G. (2011). The employee engagement landscape and HRD: How do we link theory and scholarship to current practice? Advances in Developing Human Resources, 13 (4), 419-428.

Shuck, B., Twyford, D., Reio, T. G., \& Shuck, A. (2014). Human resource development practices and employee engagement: Examining the connection with employee turnover intentions. Human Resource Development Quarterly, 25(2), 239-270.

Shuck, M. B., Rocco, T. S., \& Albornoz, C. A. (2011). Exploring employee engagement from the employee perspective: Implications for HRD. Journal of European Industrial Training, 35(4), 300-325. Doi: 10.1108/03090591111128306

Tseng, S. M., \& Lee, P. S. (2014). The effect of knowledge management capability and dynamic capability on organizational performance. Journal of Enterprise Information Management, 27(2): 158-179. 